\title{
大都市圏の耕作放棄水田における水田雑草群落復元に 向けた継続的な耕起と代かきの効果
}

\author{
The Effects of Annual Tillage and Puddling on the Restoration of Weed Communities in Abandoned Rice \\ Paddy Fields in Metropolitan Areas
}

\author{
山田 晋* 大久保 悟** 北川 淑子** 武内 和彦** \\ Susumu YAMADA Satoru OKUBO Yoshiko KITAGAWA Kazuhiko TAKEUCHI
}

\begin{abstract}
Since paddy weed communities are declining with the intensification and abandonment of agricultural activities, restoring these species become important. To confirm the occurrence of species assemblages represented in rice paddy fields, we carried out two extensive managements; tillage and puddling for four years in an abandoned paddy field in a metropolitan area. We defined specialist species in paddy fields that were represented in cultivated paddy fields and not represented in abandoned paddy fields as well as other terrestrial habitats in the study area. We also investigated restored paddy fields where rice culture was restarted, and cultivated paddy fields where local farmers practice low-intensity farming as a reference. By comparing ecological properties between experimental fields and referred fields, we sought to clarify the effect of such management regimes. As a result, although ecological properties were more or less different between experimental fields and cultivated paddy fields, the number of specialist species in paddy fields remained high throughout the experiment period in puddled plots, while in tilled plots, these species declined significantly. This indicates that annual puddling is effective enough to restore specialist species at least for four years.
\end{abstract}

Keywords: specialist species in paddy fields, Tama Hills; extensive management キーワード : 水田農業依存種, 多摩丘陵, 粗放管理

\section{1. 研究の背景と目的}

水田は日本の国土の約 7\%を占める主要な湿地環境であり, 古来, 多様な植物が生育してきた。しかし, 近年, 農業の集約化に伴い, 水田における植物相の減少が全国的に顕在化している ${ }^{6)}$ 。とりわけ 東京都心部近郊などの大都市圈では, 開発や耕作放棄による水田の 面的減少が加わり, 水田の植物相構成種数の減少に拍車がかかって いる。たとえば東京都の 2005 年における水田作付面積は, 減反政 策当初の 1971 年の約 $1 / 10$ にあたる, わずか $2 \mathrm{~km}^{2} に$ 減少した ${ }^{15)}$ 。他 の農村域に広く残るとしても, 地域ごとの個体群維持は生物多様性 の保全上重要な観点であるため, 大都市圈から失われつつある水田 自体や本来の水田雑草群落 ${ }^{13)}$ の保全は必要不可欠である。加えて 東京都では, 全国的には耕作水田で普通に生育するミゾハコベ，キ クモ，アブノメなどが希少種にリストされた ${ }^{19)}$ 。これらは耕作水田や 放棄年数のごく短い耕作放棄水田に生育するものの, 水田以外の立 地や長期間土壌舅乱が停止された耕作放棄水田には確認されないこ とから ${ }^{21)}$, 水田耕作地が消失する影響をとくに強く受けていると予 想される。したがって, このように水田農業に強く依存して生育する 種（本研究では水田農業依存種と定義する）は, 大都市圈に执いて 水田雑草群落を保全するうえでとくに重要性が高いと考えられる。

一方，水田に打ける植物相を再形成するため，放棄水田におい て植物相の復元手法が検討されてきた。こうした管理のなかで, 水田耕作の再開や, 水稲作までは行わない耕起（田起こし）ある いは代かきが実施され，土㙵攪乱を伴う管理が，水田雑草群落 ${ }^{13)}$

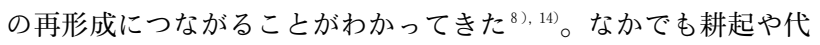
かきは, 水田耕作と比べ粗放管理であるうえ, 管理地では希少植 物の出現頻度も高いことから ${ }^{18)}$, 植物相の復元に有効な管理とし て注目されている。こうした植生管理を実際に継続して実施した 場合に, 種構成や優占種の動態を解明し, 復元事業の労力や効果 を把握することは, 行政が行う事業の評価, 市民活動の管理指針
として重要である。しかし，これまで放棄水田の植生管理に関す る研究では, 特定数種の消長に着目した報告 ${ }^{10)}$, 単年の植生管理 を行った場合の成立植生に関する報告 ${ }^{8)}$ がほとんどだった。

そこで本研究では, 耕作放棄水田において耕起と代かきによる 植生管理を 4 年間継続して実施した。現在も水稲作が行われてい る水田や, 耕作放棄水田において水稲作が再開された水田と比較 しながら，耕起管理，代かき管理によって成立した植生を，生態 学的特徵や上述の水田農業依存種の種数などに基づいて把握し, 代かきや耕起が, 水田雑草群落や, そのなかの 1 種群である水田 農業依存種の維持に対して有効か検討した。

\section{2. 研究方法}

\section{(1) 研究対象地}

本研究は多摩丘陵に位置する東京都町田市で実施した（図－1）。

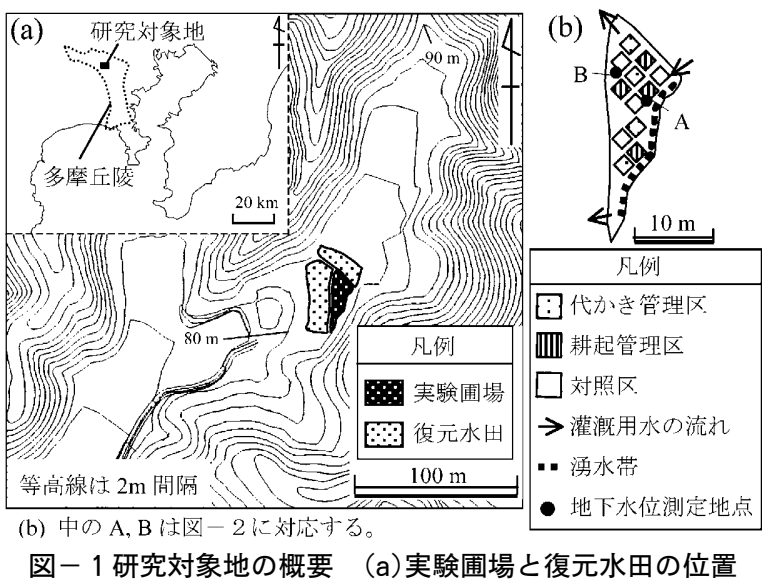

(b) 実験圃場における定置調査枠の配置

*（独）農業環境技術研究所 ${ }^{* *}$ 東京大学大学院農学生命科学研究科 


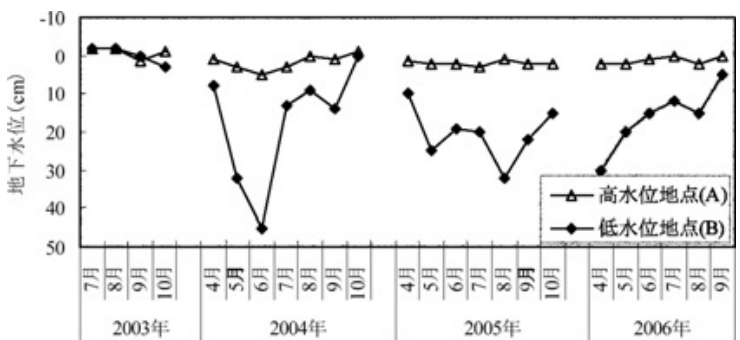

注) 管理 2 年目の 2004 年以降には代かき前に畦塗りを行わ なかったため、出水部側の水位低下が顥著だった。

図－２＼cjkstart実験圃場における地下水位の経時変化

本地域の小規模な開析谷には, 現地で谷戸田と呼ばれる排水不良 の水田が分布する。植生管理実験を実施した約 $200 \mathrm{~m}^{2}$ の放棄水田 一筆（以下，実験圃場と呼ぶ）も，そうした特徵を持つ水田だっ た。空中写真判読および聞き取りによると, この放棄水田は, 大 規模な土地改良や区画整理は行われないまま 1980 年代後半に耕 作放棄され，ヨシが優占する湿性草原へ植生遷移した。

実験圃場が存在する開析谷は東京都の歴史環境保全地域内に位 置し，1997 年に水田生態系の復元を目指した管理が開始された。 以来, 東京都の委託を受けた地元地権者からなる管理組合が, 休 耕を組み入れた水田耕作を行っている ${ }^{17)}$ 。実験圃場では 1999 年 に水田耕作が行われたが, 管理コストの問題から, その後水田耕作 は行われず，2002 年まで年 2 回程度の刈り取り管理のみが行われた。

$$
\text { 表 }-1 \text { 主な出現種一覧 }
$$

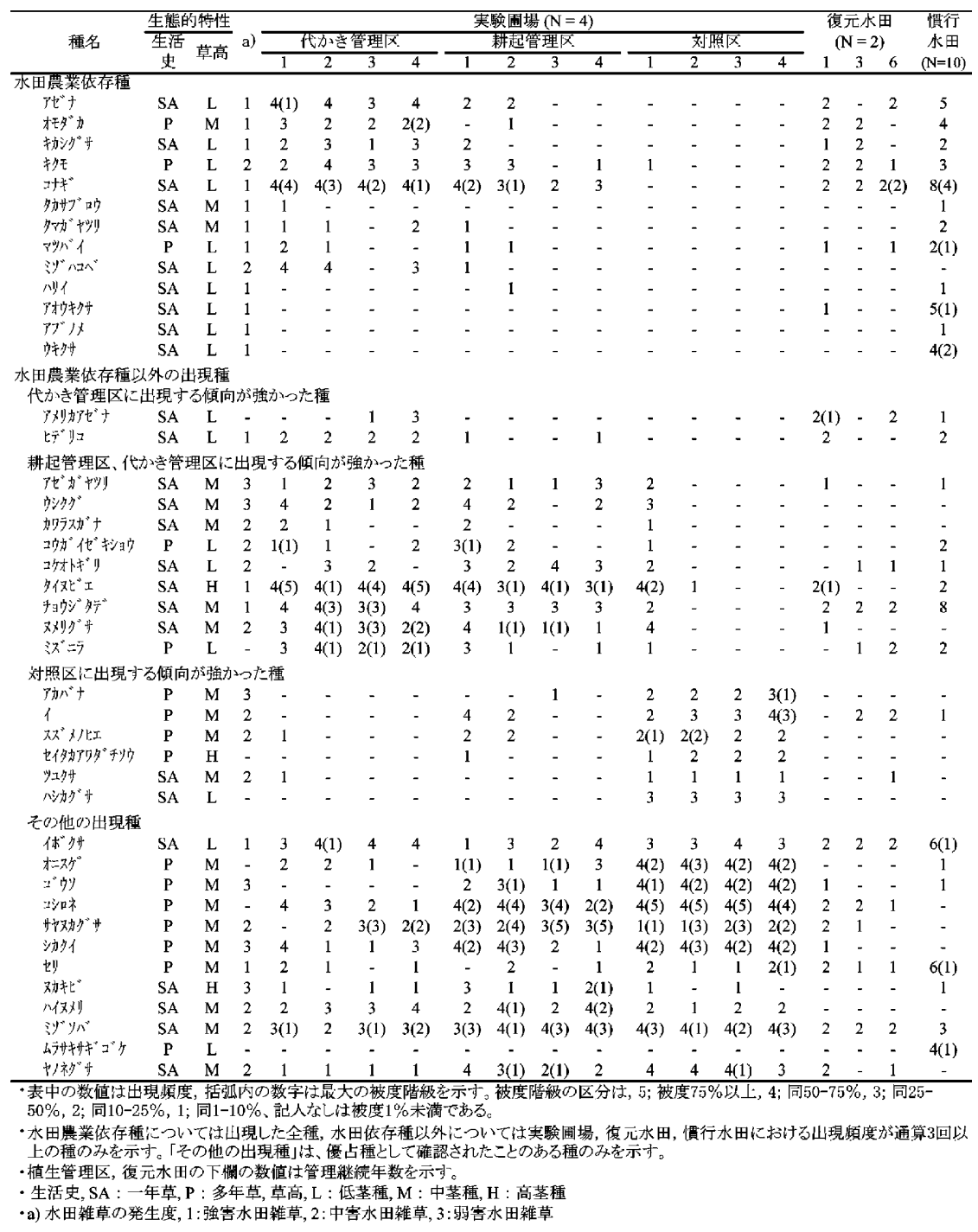

2003 年に植生管理実験が開始される直前には，コシロネ，ゴウソ などが優占するほぼ均一な相観の植物群落が成立していた。

\section{（2）植生管理方法および調査方法}

実験圃場には $2 \mathrm{~m} \times 2 \mathrm{~m}$ の定置調査枠を 12 箇所設置した。枠間 は最低 $0.5 \mathrm{~m}$ の間隔をとった。枠間に仕切は設けず，種子，栄養 繁殖体は水流によって自由に移動できるようにした（図一-1（b)）。

次に定置調查枠において，耕起（耕起のみ），代かき（耕起お よび代かき), 対照（土壌攪乱なし）の 3 つの管理を 4 つずつ実 施した。耕起では, 鍬を用いて表層土袞の深さ $15 \mathrm{~cm}$ 程度で天地 換えした。代かきでは，耕起に続き実験圃場を湛水し，目立った 植物体を定置調査枠外に除きつつ，植物体と土塊が水面下に沈む まで細砕，攪拌した。植物体が多い場合には，除ききれない植物 体を地中に踏み込んだ。（植物体を土層の下部に踏み込む作業は， ヨシの優占を抑えるために対象地域で慣行的に用いられている方 法である。）耕起, 代かきは, 1950 年代ごろまでの農事暦に合わ せ， 6 月中旬から下旬に実施した ${ }^{11}$ 。ただし，2004 年は，管理日 程の都合から 7 月 11 日となった。対照として, 土壌䚌乱を行わ ない定置調査枠を設置した。以下，耕起のみ，耕起および代かき を実施した定置調査枠を，それぞれ耕起管理区，代かき管理区之 呼び，対照として土溒攪乱を行わなかった定置調查枠を対照区と 呼ぶ。なお，対照区を含む各種管理区と定置調查枠外では，冬季 （12〜2月）に，耕起と代かき管理を妨げる枯死した地上植生を 刈り取り，植物体を除去した。

実験围場では取水部付近と出水部付近で水 位の動態が異なることが予想された。そこで, 同一植生管理の 4 定置調査枠が特定の水分条 件に偏らないよう配慮し，枠を設置した（図一 1 (b))。月 1 回程度の頻度で地下水位を測 定したところ, 出水部側は地下水位が頻繁に 低下した一方, 取水部側の地下水位は安定し て高く (図-2), 定置調査枠の配置は概ね 妥当と判断された。

植生調査は 2003 年から 2006 年の 8 月下旬 から9月上旬に行った。各定置調査枠内で全 出現種の被度（\%) と最高の草高（cm）を 記録した。

\section{（3）既存の植生データの利用}

実験圃場の成立植生と比較するため, 上記 の管理組合により水稲作が再開された水田 (以下，復元水田之呼ぶ），水稲作が毎年実施 されている水田（以下，慣行水田と呼ぶ）で 得られた既存の植生デー夕 ${ }^{21)}$ を利用した。復 元水田は, 実験戋場に隣接する戋場 2 筆であ る(図-1 (a))。この 2 筆での水田耕作は, 1998-2000，2003-2006 年に実施された。復元 水田では実験圃場之同時期に代かきが行われ， 田植え後, 水位管理, 1 回の手取り除草, 稲 刈りが行われた。慣行水田は, 実験圃場之同 様, 小規模な開析谷の未整備水田だった。田 植えは復元水田より早い 5 月中旬 6 月上旬 に行われたが，管理手法自体は類似していた。

復元水田, 慣行水田では下層植生の生育密 度が低かったため，水田内全域を対象に植生 調查を実施し，全出現種を被度とともに記録 した。復元水田の植生調查年は, 復田年当初 の 1998 年， 3 年目の 2000 年，途中 2 年間の 休耕をはさむむのの，耕作を開始してから通 算 6 年目の 2003 年だった。慣行水田の植生 
調査は 2000 年のみだった。各調查年とも 8-9 月に取得した植生 調查デー夕を解析に使用した。

\section{（4）解析方法}

実験围場における植生管理の効果を明確に把握するため, 出現 種の生態的特性（生活史, 草高) と水田雑草の発生度を整理した。 生活史は新版日本雑草図鑑16) に従い, 夏季一年草（以下，単に一 年草と呼ぶ゙), 越年草, 多年草に分類した。草高については, 全 草本植物の草高に関する情報が記載されている千葉県植物誌2), ならびに本調査結果を参考に, 低茎 (草高 $30 \mathrm{~cm}$ 未満), 中茎 (同 $30 \mathrm{~cm}-1 \mathrm{~m}$ ), 高茎 (同 $1 \mathrm{~m}$ 以上) に分類した。水田雑草の抽 出は笠原 ${ }^{7}$ に従った。同文献に記載された発生度にもとづき, 水 田雑草を, 強害水田雑草 (笠原 ${ }^{7}$ の強害草に相当する), 中害水 田雑草 (同，害草），弱害水田雑草（同，弱害草）に細分類した。

大都市圈で保全の必要性がとくに高いと考えられる水田農業依 存種は, 土袞攪乱などにより裸地が出現しやすい立地に生育する 種群であると考えられるが, 現在のところ水田農業依存種に該当 するかどうかの統一された基準が存在しない ${ }^{5)}$ 。本研究では, 一 試行例として, Yamada et $a l .{ }^{21)}$ が同地域の耕作水田植生, 耕作 放棄水田植生を対象に行った植生調查結果から, 耕作水田に生育 する湿生種であり, 耕作が放棄されると $2-3$ 年で姿を消す傾向が みられる種を水田農業依存種とした。

各種植生管理区において, 以上の分類群の出現種数が管理年次 間で有意に異なるか確認するため, R ver. 2.3.0（R development core team, 2006）を用いて反復測定による一元配置分散 分析を行った。

\section{3. 結果}

4 年間の調査の結果, 実験圃場では 57 種が確認された。主な 出現種を復元水田，慣行水田に出現した種とともに表一 1 に示す。

\section{（1）実験圃場における植生変化}

管理年次別にみた各種管理区の出現種の特徴を表－2に示す。

（i ）代かき管理区

代かき管理区における総出現種数は各年次平均 15-20 種 $/ 4 \mathrm{~m}^{2}$ で推移し，年次間に有意差はみられなかった（表 $-2, P>$ 0.05)。いずれの管理年次も出現種の半数以上は一年草であり，また， 中茎種の種数が低茎種之同等か上回った。水田雑草は出現種のほ とんどを占め, なかでも強害水田雑草の種数が最も多かった。

水田農業依存種については, 管理 3 年目において, 他の管理年 次に出現したミゾハコベ, タマガヤツリを確認できず，管理 3 年 目の種数はやや低下した (表一 1 )。オモダカは管理 3 年目と 4 年目に，地下水位が低い 2 つの定置調查枠で姿を消した。管理 3 表一2 各種管理区における出現種の生態的特性および発生度別にみた水田雑草, 水田農業依存種の種数

\begin{tabular}{|c|c|c|c|c|c|c|c|c|c|c|}
\hline & 総出現種 & 生活 & 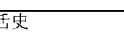 & & 容 & 水压䧸草 & & 田雑草の登生 & & 水田農鄴 \\
\hline & & 年草 & 多年草 & 低洼㮔 & 中茎種 & & 强害水田雑草 & 中害水田雓龺 & 弱害水田椺草 & \\
\hline 実騃围場 & & & & & & & & & & \\
\hline 代走き管 & 埋区 $\left(/ 4 \mathrm{~m}^{2}\right)$ & & & & & & & & & \\
\hline 1年目 & $20) .3 \pm 4.6$ & $12.8 \pm 3.0$ & $7.5 \pm 2.4 *$ & $7.3 \pm 2.1$ & $11.8 \pm 3 . \mathrm{I} *$ & $17.0 \pm 5.0$ & $8.11 \pm 2.4$ & $6.0 \pm 1.8$ & $3.0 \pm 0.8$ & $5.8 \pm 2.5$ \\
\hline 2年目 & $19.5 \pm 2.4$ & $13.3 \pm 2.2$ & $6.3 \pm 1.7$ & $9.3 \pm 1.3$ & $9.3 \pm 1.3$ & $16.5 \pm 1.9$ & $7.5 \pm 1.7$ & $7.3 \pm 1.5$ & $1.8 \pm 0.5$ & $5.8 \pm 1.7$ \\
\hline 3年日 & $15.0 \pm 5.0$ & $11.3 \pm 4.6$ & $3.8 \pm 0.5$ & $6.3 \pm 3.3$ & $7.5 \pm 2.6$ & $12.8 \pm 4.1$ & $5.8 \pm 1.0$ & $5.0 \pm 2.2$ & $2.0 \pm 1.8$ & $3.3 \pm 1.0$ \\
\hline 4年日 & $17.8 \pm 2.5$ & $12.8 \pm 1.9$ & $5.0 \pm 0.8$ & $8.0 \pm 1.4$ & $8.5 \pm 2.1$ & $15.8 \pm 2.5$ & $7.5 \pm 1.0$ & $5.5 \pm 1.7$ & $2.8 \pm 1.0$ & $5.3 \pm 1.0$ \\
\hline 耕术管理 & 区. $\left(/ 4 \mathrm{~m}^{2}\right)$ & & & & & & & & & \\
\hline 1年目 & $22.8 \pm 2.1^{* *}$ & $13.0 \pm 1.8^{*}$ & $9.3 \pm 1.0 * *$ & $7.3 \pm 0.5$ & $13.5 \pm 2.4 *$ & $19.5 \pm 1.0^{*}$ & $4.8 \pm 0.5$ & $9.8 \pm 1.7 * *$ & $5.0 \pm 1.4 *$ & $3.5 \pm 1.0^{* *}$ \\
\hline 2年目 & $18.5 \pm 3.1$ & $10.0 \pm 1.6$ & $8.5 \pm 2.4$ & $5.5 \pm 2.6$ & $12.0 \pm 1.2$ & $16.0 \pm 2.6$ & $4.8 \pm 3.3$ & $7.8 \pm 1.0$ & $3.5 \pm 0.6$ & $2.8 \pm 2.5$ \\
\hline 3年目 & $11.3 \pm 4.9$ & $8.0 \pm 2.8$ & $3.3 \pm 2.2$ & $2.8 \pm 1.7$ & $7.3 \pm 3.3$ & $9.3 \pm 4.1$ & $2.8 \pm 1.3$ & $4.3 \pm 1.3$ & $2.3 \pm 2.6$ & $0.5 \pm 0.6$ \\
\hline 4年目 & $14.0 \pm 1.2$ & $10.3 \pm 1.0$ & $3.8 \pm 1.7$ & $3.8 \pm 1.9$ & $9.0 \pm 2.2$ & $11.5 \pm 0.6$ & $3.8 \pm 0.5$ & $5.0 \pm 0.0$ & $2.8 \pm 1.0$ & $1.0 \pm 0.8$ \\
\hline 対照区（ & $\left.4 m^{3}\right)$ & & & & & & & & & \\
\hline 1年日 & $22.3 \pm 2.8 * *$ & $11.8 \pm 1.0^{* *}$ & $10.3 \pm 3.3$ & $6.3=3.2 *$ & $14.5 \pm 1.7 *$ & $17.0=1.6 *$ & $2.8 \pm 0.5 *$ & $8.8 \pm 2.1 * *$ & $5.5 \pm 1.0 * *$ & $0.3 \pm 0.5$ \\
\hline 2年日 & $14.5 \pm 3.3$ & $6.0=1.4$ & $8.5 \pm 2.4$ & $3.0=0.8$ & $10.8=2.4$ & $10.5=3.1$ & $1.3 \pm 1.3$ & $5.8 \pm 1.7$ & $3.5 \pm 0.6$ & $0.0 \pm 0.0$ \\
\hline 3年日 & $14.5 \pm 3.3$ & $5.5 \pm 1.9$ & $9.0 \pm 1.8$ & $2.3 \pm 1.0$ & $11.0 \pm 2.7$ & $10.5 \pm 2.5$ & $1.3 \pm 0.5$ & $6.0 \pm 2.0$ & $3.3 \pm 1.0$ & $0.0 \pm 0.0$ \\
\hline 4年目 & $15.8 \pm 1.7$ & $6.0=1.6$ & $9.8 \pm 1.3$ & $2.8=1.5$ & $12.3 \pm 1.7$ & $11.0 \pm 1.4$ & $1.3 \pm 0.5$ & $6.0 \pm 1.8$ & $3.8 \pm 1.0$ & $0.0 \pm 0.0$ \\
\hline 復元水田 0 & - 筆) & & & & & & & & & \\
\hline 1年目 & $24.5 \pm 6.4$ & $13.0 \pm 2.8$ & $11.5 \pm 3.5$ & $9.5 \pm 2.1$ & $11.5 \pm 2.1$ & $19.0=4.2$ & $10.0 \pm 1.4$ & $6.0 \pm 1.4$ & $3.0 \pm 1.4$ & $5.5 \pm 2.1$ \\
\hline 3年日 & $13.0 \pm 2.8$ & $6.0 \pm 0.0$ & $7.0 \pm 2.8$ & $6.0 \pm 0.0$ & $6.5 \pm 2.1$ & $11.0 \pm 1.4$ & $6.5 \pm 0.7$ & $4.0 \pm 0.0$ & $0.5 \pm 0.7$ & $4.0 \pm 0.0$ \\
\hline 6年日 & $14.0 \pm 2.8$ & $8.5 \pm 0.7$ & $5.5 \pm 3.5$ & $7.5 \pm 0.7$ & $6.5 \pm 2.1$ & $10.5 \pm 2.1$ & $6.0 \pm 1.4$ & $4.5 \pm 0.7$ & $0.0 \pm 0.0$ & $3.0 \pm 1.4$ \\
\hline 惯行水田 & 一筆) & & & & & & & & & \\
\hline & $10.3 \pm 4.1$ & $6.1 \pm 2.5$ & $3.8 \pm 2.2$ & $5.7 \pm 2.0$ & $4.1 \pm 2.9$ & $8.8=3.8$ & $6.1 \pm 3.1$ & $2.1 \pm 1.3$ & $0.6 \pm 1.0$ & $3.8 \pm 2.0$ \\
\hline
\end{tabular}

年目以外における水田農業依存種は 5 種 $/ 4 \mathrm{~m}^{2}$ 程度であり, 管理 年次による種数の有意差はみられなかった $(P>0.05)$ 。

優占種はタイヌビエやコナギ, チョウジタデなどの一年草だっ た（表一 1)。タイヌビエは管理 2 年目を除く年次で被度 $50 \%$ を 越える定置調査枠が確認され, 高い被度を維持した。管理 2 年目, 3 年目の優占種は定置調查枠の水分条件に応じて異なり, 地下水 位が低い定置調查枠ではチョウジタデ， ヌメリグサが優占した。

(ii) 耕起管理区

耕起管理区では，管理 1,2 年目に出現したウシクグ，コウガイ ゼキショウなどが管理 3 年目に姿を消し, 管理 3 年目の総出現種数, 水田雑草種数は管理 1 年目の半分程度に低下した。一年草, 多年 草の種数は管理年次によって有意に異なり（それぞれ $P<0.05, P<$ 0.01 , 表一 2$)$, 管理 3 年目に最小となった。水田雑草が出現種の ほとんどを占め, 中害水田雑草種数が最も多かった。草高につい ては，いずれの管理年次も出現種の半数以上が中茎種だった。

水田農業依存種は, 管理 1 年目には平均 3.5 種 $/ 4 \mathrm{~m}^{2}$ 出現した が，管理 3，4 年目に高い頻度で出現する種はコナギだけだった （表一 1，2）。優占種については，管理 1 年目に，3 定置調査枠 に拉いてタイヌビエが最も高い被度だったが，2 年目にはその被 度は著しく低下し, 代わってサヤヌカグサの被度が顕著に上昇し た（表一 1 ）。3 定置調査枠では, 管理 3 年目と 4 年目のサヤヌ カグサの被度がとくに高く, 70\%以上となった。地下水位が低い 1 枠ではコシロネなどが高い被度で定置調査枠を覆った。このよ うに，優占種は管理年次が進むにつれて多年草の割合が増加した。 （iii）対照区

対照区では, 管理 1 年目, アゼガヤツリ，コケオトギリなど多 くの一年草が出現し，一年草種数が多年草を上回ったが，これら の種は管理 2 年目から 4 年目には姿を消し, 一年草の種数は管理 1 年目より顕著に減少した（表- $1 ， 2$ )。一方，多年草種数は 4 年間有意に変化しなかった $(P>0.05)$ 。その結果，管理 2 年目 以降は多年草の種数が一年草を上回った。

草高に関しては, 耕起管理区と同様, 中茎種の種数が最大となっ た。発生度タイプ別にみた水田雑草についても, 耕起管理区と同 様管理年次を通して中害水田雑草の種数が最大となった。水田雑 草の種数は，管理 2 年目を除き，耕起管理区と同等だった。水田 農業依存種は，管理年次を通してほとんど確認されなかった（表一 2 )。優占種は，管理を実施する以前に優占したコシロネやシカ クイが，いずれの定置調査枠でも 4 年間優占し続けた。

\section{（2）復元水田, 慣行水田の植生}

復元水田では，圃場の全範囲で出現種を記録したにもかかわら ず, とくに耕作 3 年目, 6 年目の総出現種数, 水田農業依存種数 は，実験圃場の代かき管理区より 少なかった（表－2）。強害水田 雑草種数が中害水田雑草を上回り, 耕作 6 年目に一年草が多年草を上 回った点は代かき管理区と類似し た。一方, 低茎種の種数が中茎種 を上回り, 耕作 6 年目に弱害水田 雑草が姿を消す点は, 代かき管理 区と異なった。復元水田で出現し た水田農業依存種のうち, アオウ キクサを除く全種が代かき管理区 に確認された（表一1）。逆に，代 かき管理区に出現したタカサブロ ウ, ミゾハコベ, タマガヤツリは 復元水田にみられなかった。

慣行水田の総出現種数は復元水 田よりも少なかった（表－2）。 
水田雑草として出現した種のほとんどは強害水田雑草だった。水 田農業依存種については, 実験圃場で出現しなかったアオウキク サ，ウキクサ，アブノメの 3 種を含む 12 種記録された（表－1）。 水田農業依存種以外で慣行水田のみに出現した種は，ムラサキサ ギゴケ，スギナなど，畦畔から侵入したと思われる種だった。一 年草種数が多年草種数を, 低茎種数が中茎種数を上回った。

\section{4. 考察}

本研究の結果, 実験圃場, 復元水田, 慣行水田では, それぞれ 異なるタイプの成立植生が確認された。慣行水田の成立植生は種 組成からウリカワーコナギ群集 ${ }^{13)} に$ に位置づけられる。この群集の 標徵種にはコナギ, キカシグサなどがあり, 慣行水田で確認した 一年草, 低茎種が卓越する結果と類似した。一方, 土㙵攪乱が行 われなかった対照区では, とくに管理 2 年目以降, 多年草, 中茎 種, 中害水田雑草が卓越した。耕起管理区, 代かき管理区, 復元 水田は, 慣行水田と対照区の中間的な種構成の特徵を示し, 耕起 管理区, 代かき管理区, 復元水田へと管理強度が増すにつれ, 慣 行水田の種構成の特徵に近づいた。休耕田の植生管理により多年 草の割合が低下し, 低下の程度は刈り取り管理より耕起管理で大 きいこと ${ }^{4)}$, 代かき管理が施された休耕田は水田雑草中心の種組 成となり, 耕起管理は代かき管理と比較してょり高茎の種が多い

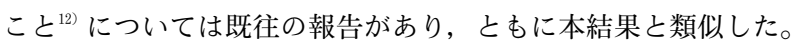

代かき管理によって成立した植生は，一年草と強害水田雑草が 卓越した点で慣行水田と一致した。しかし, 中茎種が低茎種を上 回り, 中害および弱害水田雑草も一定の割合で生育した点, また $4 \mathrm{~m}^{2}$ という小面積に, より多くの種が高密度で出現した点では, 慣行水田で成立する水田雑草群落と異なる群落が形成されたと考 えられる。この原因は管理手法の違いに大きく起因する。たとえ ば, 慣行水田では, 代かきに加え, 手取り除草により水田区画の 植物は取り除かれるが，攪乱が頻繁に行われる環境ほど，発芽か ら成長までの期間を短くすることができる低茎種の生育に適した 環境となることが知られている3。。また, イネによって下層の光 環境が低下しやすい水田耕作地に適応した多くの水田雑草は, 遮 光下で積極的に発芽を抑制する性質を持つことが知られている1)。

一方, 本研究で保全価值が高いとして注目した水田農業依存種 については, 代かき管理区では, 限られた面積に, より多種が出 現した。管理年次による種数の有意な差はみられず，代かきはこ れらの種を複数年にまたがり維持する点で有効な管理であると考 えられた。また，慣行水田にはみられないヌメリグサ， ウシクグ などの中茎の中・弱害水田雑草を含んだことから, 耕作水田より も幅広い生態的特性を有する植物種の生育地としても評価するこ とができる。代かき管理区では，上述した除草やイネ優占に伴う 遮光がなかったうえ, 水田雑草の中には, 代かきに適応した生活 パターンを獲得している種が少なくない。たとえば，コナギの種 子は湛水下などの低酸素状態において発芽が促進される ${ }^{9)}$ 。さら に, 耕起管理区で優占した多年草が代かき管理区で顕著に低い被 度だった原因は, 土袞の細砕, 捏ね, 均しといった, 耕起にない 一連の過程が植物体を破壊したことにも起因する可能性がある。

耕起管理区における深さ $15 \mathrm{~cm}$ での土塊ごとの天地返しのみで は, 多年草の根茎が切断されつつもまとまって残り, 多年草の優 占化を招いた。本論で提案した水田農業依存種や, 管理当初は代 かき管理区よりも種数が多かった中・低害水田雑草は, 管理年次 とともに有意に減少した。すなわち, それらの保全を図るうえで 耕起管理は継続的な管理手法として不適であると考えられた。

耕起に加えた代かきを行うことは, 耕起のみの場合の 2 倍の労 力を必要とする ${ }^{20)}$ 。しかし, 代かき管理は水田耕作と比較すれば $1 / 6$ 程度の作業量であり ${ }^{20)}$, 復元手法として, 水稲作を選ぶより も大幅に粗放的な管理として評価できる。また, 本研究の植生管
理を実際行った際，多年草の根茎が存在する管理 1 年目の代かき 管理は，その後の年次よりも作業量は大きかった。したがって, 代かき管理が多年草の優占化を抑えたことは，作業効率の面の効 果が一層大きいと考えられる。

\section{5. まとめと今後の課題}

代かきによって管理された耕作放棄水田の成立植生は，水田雑 草群落とは異なったが，大都市圈の耕作水田において維持する必 要性が高い水田農業依存種を, 少なくとも 4 年間の期間内では維 持する点で有効な管理手法だった。本研究では, 一部の定置調査 枠で水分条件を十分制御できず，水分条件の違いによって，優占 種や水田農業依存種のオモダカなどの出現傾向が変化した。水分 条件は水田や休耕田の植生に影響を与える要因のひとつである ${ }^{12}$ 。 今後, 放棄水田における植物相復元の際には, 水分条件を考慮し て植生管理やその効果の検証を行う必要がある。慣行水田にみら れたアオウキクサ, ウキクサ, アブノメの 3 種が実験圃場に出現 しなかった理由は不明であり, そうした種の繁殖器官の生存期間, 圃場間での分散能力などについても検討する必要があるだろう。

\section{参考文献}

1 ）浅野紘臣（2001）：水田雑草の発生に及ぼす遮光の影響：雑草研究 $46,31-36$

2 ) 千葉県史料研究財団編（2003）：千葉県の自然誌 別編 4 千葉県植物 誌：千葉日報社, 千葉. 1181pp.

3 ) Grime, J.P. (1977): Evidence for the existence of three primary strategies in plants and its relevance to ecological and evolutionary theory. American Naturalist 111, 1169-1194

4 ）箱山晋・田中日吉・縣和一・武田友四郎（1977）：休耕田の植生遷移 に関する研究：日本作物学会記事 $46,219-227$

5 ）日鷹一雅・嶺田拓也・榎本敬（2006）：湿生植物 RDB 掲載種の農業 依存性評価一博物館等の収蔵標本における採集地記載情報を用いた一 事例加ら-：保全生態学研究 22, 124-132

6 ）環境庁編（2000）：改訂・日本の絶隇のおそれのある野生生物 8 植物 I（維管束植物）：自然環境研究センター, 東京, $660 \mathrm{pp}$.

7 ）笠原安夫（1951）：本邦雑草の種類及地理的分布に関する研究 第 4 報 水田雑草の地理的分布と発生度: 農学研究 $39,143-154$

8 ）柏原一凡・夏原由博・森本幸裕（2005）：環境と植生の異なる放棄水 田における草刈および耕起による植生変化の事例：ランドスケープ研 究 $68,669-674$

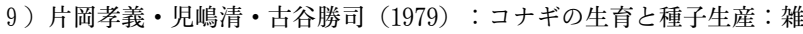
草研究 $24,86-91$

10）小荒井晃・芝山秀次郎（2001）：水田の代かき後における数種一年生 雑草の発生消長と出芽深度 : 雑草研究 46, 5-12

11）町田市誌編纂委員会編（1976）：町田市誌下卷：第一法規出版，東京. $1718 \mathrm{pp}$.

12）嶺田拓也・石田憲治・飯嶋孝史・松森堅治（2005）：中山間地休耕田 の効率的維持管理に向けた植生指標の検討：農業土木学会論文集 237, $75-80$

13）宮脇昭・奥田重俊・藤原陸夫（1994）：改訂新版日本植生便覧：至文 堂, 東京. $910 \mathrm{pp}$.

14）中本学・関岡裕明・下田路子・森本幸裕（2002）：復田を組み入れた 休耕田の植生管理 : ランドスケープ研究 $65,585-590$

15）農林水産省統計部（2006）：耕地及び作付面積統計：農林水産省，東 京. 283pp.

16）沼田真・吉沢長人編（1997）：新版日本原色雑草図鑑：全国農村教育 協会, 東京, $414 \mathrm{pp}$.

17）斉藤勝成（1998）：図師小野路歴史環境保全地域一新たな谷戸管理手 法の確立を目指してー: ランドスケープ研究 61,312-313

18）関岡裕明・下田路子・中本学・水澤智・森本幸裕（2000）：水生植物 および湿生植物の保全を目的とした耕作放棄水田の植生管理：ランド スケープ研究 $63,491-494$

19）東京都環境局（1998）：東京都の保護上重要な野生生物種：山広印刷 所, 東京. $77 \mathrm{pp}$.

20）東京都多摩環境保全事務所・自然教育研究セン夕ー（1996）：保全地 域における谷戸の管理手法調查報告書, $160 \mathrm{pp}$.

21) Yamada, S., Okubo, S., Kitagawa, Y. and Takeuchi, K. (2007) : Restoration of weed communities in abandoned rice paddy fields in the Tama Hills, central Japan: Agriculture, Ecosystems and Environment 119, 88-102 